\title{
An Economic Analysis of the South-North Bali Connection Railway Plan in The Acceleration of Economic Equality Development in Bali, Indonesia
}

\author{
Dewa Ketut Sudarsana
}

\begin{abstract}
At present the economic development in the province of Bali between South and North Bali is very significant. This condition is presumed to be the transportation infrastructure for the connecting road of South Bali - the existing aiIDRort is not optimal. The alternative transportation infrastructure studied is the plan to build a railway line across South-North Bali. Mengwitani-Singaraja link road is required to be capable to provide more optimal accessibility so that there is an even distribution of economic growth.he indicators used in the feasibility analysis of economic aspects are net present value (NPV), benefit cost ratio (BCR) and economic internal rate of ruturn (EIRR) The price component is used by the shadowprice method. Costs calculated according to the life cycle cost of the project development. Benefits calculated include direct benefits in the form of passenger ticket income and indirect costs in the form of cost savings for existing road users, a multiplier effect, an increase in tourist visits to northern Bali. Economic analysis indicates that the planned North-North Bali railway line is worth proceeding, this is shown by the NPV indicator of IDR 860 billion, BCR of 1.11 and EIRR of $13.11 \%$ greater than the $12 \%$ price reduction rate. Although it shows that there is feasibility of economic studies, a strategy is needed to produce financial feasibility so that it can be offered in cooperation between government and business entities (PPP) in order to accelerate its development.
\end{abstract}

Index Terms-Economic Analysis; Disparity; Development; Railway; NPV; EIRR.

\section{INTRODUCTION}

Bali Island is a tourist destination of domestic and foreign tourists, with tourist destinations almost evenly distributed in Bali. The geographical area of the island of Bali has a mountainous and hilly area so that it becomes an obstacle of connectivity between regions, especially in the northern region of Bali [1], [2]. The current infrastructure conditions of the north-north Bali road are mainly from the Baturiti village (Tabanan) in Sukasada village (Singaraja), the alignment does not meet as an arterial road [2]. The impact of this condition is the discomfort of road users. A really significant impact is considered from the aspect of economic growth, that is to say the gap in economic growth between southern Bali and northern Bali.d northern Bali. Efforts to improve this alignment are only the stages of studies [2]. The alternative mode of transportation planned to be developed is by train mode. It is expected that the existence of this railway network infrastructure can be an alternative mode of transportation that makes connectivity between the two regions and improving the service system in the long

Published on March 31, 2019.

D. K. Sudarsana is with Udayana University, Indonesia. run, serving passenger flow movements so that time and travel costs can be achieved while increasing interaction between the northern and southern parts of Bali [1]. To see the feasibility of planning alternative railway network modes requires a study of technical, social, cultural, environmental, economic and financial aspects. This specific paper discusses the feasibility of economic aspects.

\section{MATERIALS AND METHODS}

As an object in the study of economic aspects, the planned construction of railway lines is a plan for crossing North-North Bali. In southern Bali starting from Mengwitani precisely the Mengwi terminal and the final destination are north Bali at Singaraja precisely at Sangket terminal, Sukasada. This economic aspect study was carried out after getting the best alternative routes from technical, environmental and social-cultural studies. The economic feasibility indicator uses the net present value (NPV) indicator, cos ratio (BCR) benefit and internal rate of return (IRR) [4], [5], [7], [9]. For IRR in economic studies the term economic internal rate of return (EIRR) is used. The development plan is said to be feasible if the NPV value is> 0, BCR> 1 and EIRR> discount rate.

\section{A. Net Present Value (NPV)}

This NPV approach tries to assess the economic performance of an alternative planning by taking into account the difference in the value of benefits and the cost of each alternative throughout the planning period. The difference in value is then estimated by its present value (project base year) by reducing its value due to the discount rate that is expected to occur throughout the planning time. According to [4], the Net Present Value (NPV) is a method for calculating the net value at present. The NPV method in principle is to move the existing cash flow in the entire investment age of the initial investment time $(\mathrm{t}=0)$ or called the present condition. In this case the reference used is the current net amount (Net Present Value), meaning that all the magnitude of the benefit and cost components change in the present value.

The benefits component is now known as the Present Worth of Benefit (PWB), and the cost component is now known as the Present Worth of Cost (PWC). NPV is obtained from the PWB calculation minus PWC. PWB is formulated as in (1), PWC is formulated as in (2) and NPV is formulated as in (3) [4].

$$
P W B=\sum_{t=0}^{n} C b_{t}(F B P)_{t}
$$




$$
\begin{aligned}
& P W C=\sum_{t=0}^{n} C c_{t}(F B P)_{t} \\
& N P V=P W B-P W C
\end{aligned}
$$

Where:

$$
\begin{aligned}
& \text { PWB } \quad \text { Present Worth of Benefit } \\
& \text { PWC } \quad=\text { Present Worth of Cost } \\
& \mathrm{Cb} \quad=\text { Cash Flow Benefit } \\
& \mathrm{Cc} \quad=\text { Cash Flow Cost } \\
& \mathrm{FBP}=\text { Present Flower Factor } \\
& \mathrm{t}=\text { time period } \\
& \mathrm{n}=\text { investment life period }
\end{aligned}
$$

\section{B. Benefit Cost Ratio (BCR)}

Benefit Cost Ratio (BCR) is the ratio of total costs (C) to total benefits (B) in each year of review, which is done by converting these values to the base year taking into account the discount rate. Mathematics the BCR is formulated as in (4) $[4]$.

$B C R=\frac{P W B}{P W C}$ or $\frac{\sum_{t=0}^{n} C b_{t}(F B P)_{t}}{\sum_{t=0}^{n} C c_{t}(F B P)_{t}}$

\section{Internal Rate of Return (IRR)}

IRR is a value of the interest rate (discount rate) when the present value of the investment benefit equals the present value of the investment cost, or the interest rate at the time when the NPV value is 0 . 0 . The IRR can be calculated as in (5) [4]. For economic studies the term Economic IRR (EIRR) is used.

$I R R=E I R R=i_{1}+\frac{N P V^{+}}{N P V^{+}+N P V^{-}}\left(i_{2}-i_{1}\right)$

\section{Benefits Prediction}

Benefits are calculated in the form of direct benefits in the form

\section{1) Road User Cost Savings (PBPJ)}

Road user costs (PBPJ) or benefits of Road User Costs (PBPJ):

$P B P J=\left(B O K_{L} x D_{L}-B O K_{B} x D_{B}\right)\left\{\left(\frac{D_{L}}{V_{L}}-\frac{D_{B}}{V_{B}}\right)\right\} x T_{V}$

Where :

PBPJ = Road User Cost Savings (IDR.);

BOK $_{\mathrm{L}}=$ Vehicle Operating Costs when running the existing road (IDR. / km);

$\mathrm{BOK}_{\mathrm{B}}=$ Vehicle Operating Costs when running a new $\operatorname{road}(\mathrm{IDR} . / \mathrm{km})$;

$\mathrm{D}_{\mathrm{L}} \quad=$ Distance traveled if through the existing road $(\mathrm{km})$;

$\mathrm{D}_{\mathrm{B}}=$ Distance traveled if through a new road $(\mathrm{km})$;

$\mathrm{V}_{\mathrm{L}} \quad=$ Speed of the vehicle when running through the $\mathrm{road}(\mathrm{km} / \mathrm{hour})$;

$\mathrm{V}_{\mathrm{B}}=$ The speed of the vehicle when running a new existing road ( $\mathrm{km} /$ hour);

$\mathrm{T}_{\mathrm{V}} \quad=$ Value of time savings (IDR. / hour).

\section{2) Multiplier Effect of Foreign Tourist Expenditures}

Other indirect benefits by calculating the mulplier effect from the prediction of foreign tourist spending with the railway track [1]

The following is the magnitude of the multiplier coefficient of Bali Province, presented in Table I.

TABLE I: COEFFICIENT OF MULTIPLICATION OF BALi PROVINCE [1]

\begin{tabular}{llll}
\hline \hline Multiplier coefficient & Direct & Indirect & Induced \\
\hline $\begin{array}{l}\text { Tourism impact on GDP } \\
\text { The impact of tourism on Regional }\end{array}$ & 0.368 & 0.499 & 0.930 \\
$\begin{array}{l}\text { Original Income } \\
\begin{array}{l}\text { The impact of tourism on } \\
\text { employment }\end{array}\end{array}$ & 0.053 & 0.056 & 0.090 \\
\hline
\end{tabular}

\section{3) Passenger Ticket Income}

\begin{tabular}{|c|c|c|}
\hline No & Component/Description Cost & $\begin{array}{c}\text { Cost (IDR. } \\
\text { Million) }\end{array}$ \\
\hline A & Land Acquisition Fee & 220.000 \\
\hline B & Construction and Facility Costs & 6.635 .829 \\
\hline $\mathrm{C}$ & $\begin{array}{l}\text { Study Services, DED, Construction } \\
\text { Management }(1 \% \text { x B) } \\
\text { Total Initial Investment }(A+B+C)\end{array}$ & $\begin{array}{r}66.358 \\
6.992 .187\end{array}$ \\
\hline $\mathrm{D}$ & Annual Operational \& Maintenance Costs & 89.244 \\
\hline $\mathrm{E}$ & Periodic Maintenance (5 years) & 331.791 \\
\hline
\end{tabular}

Estimated passenger ticket prices with parametric method, using the passenger ticket price approach that applies in Java regional.

\section{RESULTS AND DISCUSSION}

\section{A. Estimated Costs}

Estimated costs follow the project life cycle cost, starting from

TABLE II: ESTIMATED COSTS

\section{B. Benefits Prediction}

1) a. BOK or VOC savings prediction.

\begin{tabular}{|c|c|c|c|}
\hline Year to & Year & $\begin{array}{c}\text { VOC Saving } \\
\text { (IDR. millions) }\end{array}$ & $\begin{array}{l}\text { Time Value Saving } \\
\text { (IDR. millions) }\end{array}$ \\
\hline
\end{tabular}

BOK or VOC (Vehicle Operating Cost) savings predictions obtained from the condition of road users using the previous motorized vehicle mode through the existing road, then switching to using the railway mode. In the initial year of operation (in 2021) the prediction of VOC savings is IDR 1687 million, can be seen in Table III column 3 .

TABLE III: PREDICTION OF BOK OR VOC SAVINGS AND TIME VALUE SAVINGS

$\begin{array}{cccc}(1) & (2) & (3) & (4) \\ 0 & 2020 & & \\ 1 & 2021 & 1687 & 28,353 \\ 2 & 2022 & 1830 & 33,850 \\ 3 & 2023 & 1976 & 40,231 \\ 4 & 2024 & 2124 & 47,625 \\ 5 & 2025 & 2274 & 56,180 \\ 6 & 2026 & 2426 & 66,066 \\ 7 & 2027 & 2656 & 79,827 \\ 8 & 2028 & 2890 & 95,863 \\ 9 & 2029 & 3127 & 114,515 \\ 10 & 2030 & 3367 & 136,169 \\ 11 & 2031 & 3611 & 161,267 \\ 12 & 2032 & 3858 & 190,312\end{array}$




\begin{tabular}{llll}
13 & 2033 & 4108 & 223,879 \\
14 & 2034 & 4362 & 262,618 \\
15 & 2035 & 4619 & 307,273 \\
16 & 2036 & 4879 & 358,688 \\
17 & 2037 & 5332 & 433,400 \\
18 & 2038 & 5791 & 520,466 \\
19 & 2039 & 6257 & 621,730 \\
20 & 2040 & 6730 & 739,295 \\
21 & 2041 & 7210 & 875,559 \\
22 & 2042 & 7696 & $1,033,254$ \\
23 & 2043 & 8190 & $1,215,493$ \\
24 & 2044 & 8097 & $1,311,273$ \\
25 & 2045 & 7873 & $1,381,087$ \\
26 & 2046 & 7291 & $1,428,818$ \\
27 & 2047 & 6505 & $1,395,675$ \\
28 & 2048 & 5701 & $1,325,878$ \\
29 & 2049 & 4898 & $1,209,853$ \\
30 & 2050 & 4124 & $1,036,063$ \\
\hline
\end{tabular}

\section{2) Time Value Savings}

In this time saving analysis, only the value of the passenger time of the existing road user is calculated after the railway. The value of passenger time is calculated by the province's minimum wage UMP [11]. The UMP for the calculation year is 2015 with a value of IDR $1,807,600$ per month, assuming 4 working weeks, 6 working days and 8 working hours. So the value of passenger time is IDR 9,415 per hour.

The average vehicle occupancy level is $\mathrm{MC}=1.35$ passengers; $\mathrm{LV}=2.7$ passengers; $\mathrm{HV}$ consists of Golonag IIA $($ Bus $)=24.15$ and Group IIB (truck) $=1.98$. The time value savings obtained are presented in Table III column 4.

\section{3) Multiplier Effect of Increasing Foreign Tourists}

The increase in spending on foreign tourists predicted in 2021 is IDR 204,395,000,000, by multiplying the coefficient in Table I, it can be predicted that the multiplier effect of 2021 is IDR 500,463,000,000.0. The description of this value is presented in Table IV.

TABLE IV: MULTIPLIER EFFECT PREDICTIONS OF TOURIST SPENDING IN THE PRESENCE OF TRAINS

\begin{tabular}{lc}
\hline \hline The coefficient of multiplying & IDR. million \\
\hline Impact of tourism on GRDP B & 367,297 \\
The impact of tourism on ROI & 34,747 \\
The impact of tourism on employment & 98,518 \\
\hline Total & 500,563 \\
\hline \hline
\end{tabular}

\section{4) Prediction of Passenger Ticket Income}

Prediction of passenger ticket income can be seen in Table V Column 3.

TABLE V: PREDICTION OF PASSENGER TICKET INCOME

\begin{tabular}{ccc}
\hline \hline Year to & Year & $\begin{array}{c}\text { Ticket } \\
\text { millions) }\end{array}$ \\
\hline$(1)$ & $(2)$ & $(3)$ \\
0 & 2020 & \\
1 & 2021 & 100,084 \\
2 & 2022 & 128,433 \\
3 & 2023 & 158,219 \\
4 & 2024 & 189,499 \\
5 & 2025 & 222,331 \\
6 & 2026 & 282,453 \\
7 & 2027 & 322,185 \\
8 & 2028 & 363,831 \\
9 & 2029 & 407,464 \\
10 & 2030 & 453,161 \\
11 & 2031 & 551,101 \\
12 & 2032 & 606,172 \\
13 & 2033 & 622,296 \\
14 & 2034 & 638,849
\end{tabular}

\section{5) Scenario 3: Components of Benefits include} Increasing Tourists' Visits

With the crossing of the Mengwitani-Singaraja railway, it has the potential to increase foreign tourists' visits to North Bali. The increase tourist tour to North Bali will benefit the economic multiplier effect. In addition, around the railway station plan also has the potential to be developed as transit oriented development (TOD).

The analysis results by including the increase in the GRDP of the construction of railway lines across NorthSouth Bali, an analysis of economic feasibility indicates economic viability, this is indicated by economic indicators. obtained as follows:

$\begin{array}{ll}\text { NPV } & :+ \text { IDR } .860,419.5 \text { billion }>0 \\ \text { BCR } & : 1,11>1 \\ \text { EIRR } & : 13.11 \%>12 \%\end{array}$

Payback Period : 24th year

This description of pay back period from economic indicators is presented in Fig. 1.

With the indicators obtained, it can be recommended that the construction of the Mengwitani - Singaraja (South Bali north) railrway, can go to the next stage, such as Trase Study.

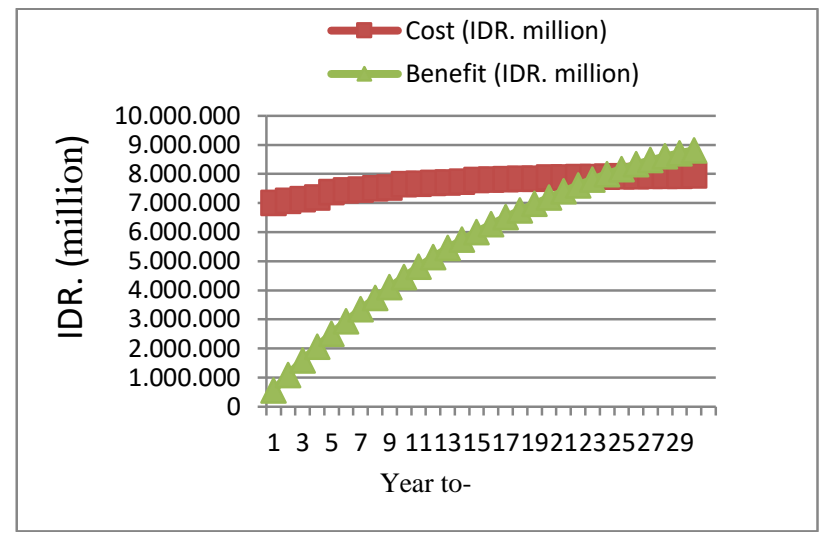

Fig. 1. Payback Period occurs 24 years

\section{CONCLUSION}

The South Bali (Mengwitani, Badung) Railrway Development Plan across North Bali (Sukasada, Singaraja) shows the feasibility of having feasibility indicators such as $\mathrm{NPV}=+$ IDR 860,419.5 billion $>0, \mathrm{BCR}=1.11>1, \mathrm{EIRR}=$ $13.11 \%>12 \%$, and Payback Period in 24th year. Given the limited government budget, a financial feasibility study 
needs to be carried out, with the hope of providing a description of a third party, namely the private sector or business entity in an effort to participate in an investment. The potential that can be developed is the concept of Transit Oriented Development (TOD), in 3 districts that are crossed by the railway plan, namely Badung, Tabanan and Buleleng.

\section{ACKNOWLEDGMENTS}

Our gratitude goes to the colleagues of the consultant team, the Bali Provincial Transportation Agency and related parties in the Pre-Feasibility Study of the Cross-Railway Link Mengwitani - Singaraja.

\section{REFERENCES}

[1] Anonim.2016. Laporan Akhir Feasibility Studi Jalur Kereta Api Lintas Mengwitani Singaraja. Dinas Perhubungan Bali.

[2] Bapeda Bali (Badan Perencanaan Daerah I Bali). 2006. Pra Studi Kelayakan Jalan Penghubung Bali Utara-Selatan

[3] Ervianto, W. 2005. .Manajemen Proyek Konstruksi. Yogyakarta : Andi Offset.

[4] Giatman M. 2017. Ekonomi Teknik. Rajagrafindo Persada, Depok Jakarta

[5] Ibrahim, B. 1993. Rencana dan Estimate Real of Cost, Bumi Aksara, Jakarta.

[6] Jumingan. 2011. Studi Kelayakan Bisnis. Bumi Aksara, Jakarta
[7] Kodotie R.J. 1995. Analsisi Ekonomi Teknik. Andi Offset, Yogyakarta

[8] Nugraha, P., Natan, I., Sutjipto, R. 1985. Manajemen Proyek Konstruksi . Kartika, Surabaya

[9] Pujawan N. 1995. Ekonomi Teknik. Guna Widya, Jakarta

[10] PMI (Project Management Institute). 2015. Project Management Body of Knowledge. USA

[11] Sudarsana DK. 2014. Model Kerugian Pengguna Jalan Pada Proyek Rekonstruksi Jalan. Disertasi. Program Doktor Teknik Sipil, Fakultas Teknik, Universitas Brawijaya, Malang.

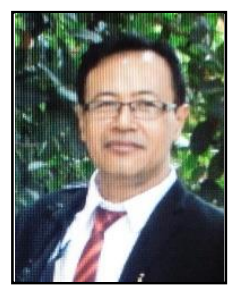

Dewa_Ketut_Sudarsana, born February 5, 1963 in Singaraja, Bali, Indonesia. Completed the Doctoral Program in Civil Engineering with a concentration in Transportation Management, in Brawijaya University, Malang, East Java, Indonesia.

Research interest in road infrastructure management, from the initiation stage (feasibility study), execution period (safety aspects, negative mitigation and contract).

Our publications include: The Analysis to Minimize the Loss of Fuel during National Road Maintenance Project in Bali, Indonesia, International Journal of Engineering and Technology (Dr. Sudarsana), Development of Assessment Tools for Road Safety Performance during Execution of National Road Project Improvement in Bali-Indonesia (Dr. Sudarsana), Analysis of loss of time value during road maintenance project (Dr. Sudarsana), Risk Analysis of Tender Documents on the Execution of Private Construction Work at Badung Regency, Bali Province, Indonesia (Dr. Sudarsana). Association membership such as: International Sustainable Development Society, ID: M172361 and World Road Association-PIARC, ID :IDP002. 